\title{
Digital Microfluidics for Single Bacteria Capture and Selective Retrieval Using Optical Tweezers
}

\author{
Phalguni Tewari Kumar ${ }^{1,+}{ }^{+}$, Deborah Decrop ${ }^{1,+}$, Saba Safdar ${ }^{1,+}$, Ioannis Passaris ${ }^{2}$, \\ Tadej Kokalj ${ }^{1}$, Robert Puers ${ }^{3}$, Abram Aertsen ${ }^{2}$, Dragana Spasic ${ }^{1}$ and Jeroen Lammertyn ${ }^{1, * \mathbb{C}}$ \\ 1 Department of Biosystems, Biosensors Group, KU Leuven, 3001 Leuven, Belgium; \\ phalgunitewari@gmail.com (P.T.K.); deborah.decrop@gmail.com (D.D.); saba.safdar@kuleuven.be (S.S.); \\ tadej.kokalj@imt.si (T.K.); dragana.spasic@kuleuven.be (D.S.) \\ 2 Department of Microbial and Molecular Systems, KU Leuven, 3001 Leuven, Belgium; \\ ioannis.passaris@gmail.com (I.P.); abram.aertsen@kuleuven.be (A.A.) \\ 3 ESAT-MICAS, Microelectronics and Sensors, KU Leuven, 3001 Leuven, Belgium; robert.puers@kuleuven.be \\ * Correspondence: jeroen.lammertyn@kuleuven.be; Tel.: +321-632-1459 \\ + These authors contribute equally.
}

Received: 28 February 2020; Accepted: 14 March 2020; Published: 15 March 2020

\begin{abstract}
When screening microbial populations or consortia for interesting cells, their selective retrieval for further study can be of great interest. To this end, traditional fluorescence activated cell sorting (FACS) and optical tweezers (OT) enabled methods have typically been used. However, the former, although allowing cell sorting, fails to track dynamic cell behavior, while the latter has been limited to complex channel-based microfluidic platforms. In this study, digital microfluidics (DMF) was integrated with OT for selective trapping, relocation, and further proliferation of single bacterial cells, while offering continuous imaging of cells to evaluate dynamic cell behavior. To enable this, magnetic beads coated with Salmonella Typhimurium-targeting antibodies were seeded in the microwell array of the DMF platform, and used to capture single cells of a fluorescent $S$. Typhimurium population. Next, OT were used to select a bead with a bacterium of interest, based on its fluorescent expression, and to relocate this bead to a different microwell on the same or different array. Using an agar patch affixed on top, the relocated bacterium was subsequently allowed to proliferate. Our OT-integrated DMF platform thus successfully enabled selective trapping, retrieval, relocation, and proliferation of bacteria of interest at single-cell level, thereby enabling their downstream analysis.
\end{abstract}

Keywords: optical tweezers; single-cell; digital microfluidics; Salmonella Typhimurium

\section{Introduction}

Heterogeneity exists at every level in living systems, from whole organisms down to single cells. Between individual cells, heterogeneity occurs at the genetic and molecular level, due to stochastic gene expressions, age of cells, asymmetric partitioning during cell division, and inhomogeneous cellular environments [1-5]. Therefore, each cell is unique in its behavior and reactions. It is thus imperative to understand an organism or population down to the individual cell level, which might be essential to delineate complex processes more efficiently, such as the evolution of cancer [6,7], bacterial population dynamics [8-10], effect of environmental stimuli at gene-levels [11,12], and modeling of disease prognosis [13,14].

To more selectively analyze a particular cell of interest from a consortium, its retrieval is pivotal. Various solutions have been proposed to date for enabling this. For instance, commercially available fluorescence activated cell sorting (FACS)-based techniques have found extensive applications in cell analysis, primarily for the identification and sorting of individual cells based on their total 
fluorescence [15]. In addition, myriad other automated and semi-automated techniques based on surface engineering and microfluidics have been investigated in this context [16-22]. Merely a few examples of such novel technologies for single-cell analysis are: single-cell chromosomal analysis using micropillars [20], monitoring of bacterial drug efflux activity using a hydrophilic-in-hydrophobic $(\mathrm{HIH})$ micropatterned surfaces [21], real-time analysis of individual erythrocytes [17], and real-time cytokine detection [23].

Another technology that has been successfully used for a variety of biological applications, including trapping and sorting of single cells, is optical tweezers (OT) technology (e.g., cell-fusion [24], red blood cell aggregation [25] and deformability [26], microsurgery to hold fragments of chromosomes [27], cell adhesion [28], and cell viability [29,30]). To demonstrate trapping and sorting of single cells, OT have been integrated with channel-based microfluidic platforms. However, the latter can introduce certain level of complexity for liquid manipulation because of their dependence on complex microchannel networks, pumps, and valves [31-35]. Interestingly, the emerging field of digital microfluidics (DMF) has been explored for achieving high throughput single-cell trapping in microwell arrays in a less complex manner, by manipulating fluid droplets on a planar surface $[36,37]$ using electrowetting on dielectric principle (EWOD). To manipulate single magnetic beads (MBs) seeded in a microwell array, Decrop et al. $[38,39]$ recently integrated OT with a DMF platform. They demonstrated that Brownian motion of seeded MBs was essential to optically manipulate MBs. Ionic strength and non-ionic surfactants were altered in a phosphate buffered saline (PBS) buffer to increase electrostatic repulsion and impart steric stabilization, respectively, which increased Brownian motion of the MBs. However, to the best of our knowledge, the manipulation of single cells, trapped in a microwell array, for enabling controlled single-cell analysis has not yet been reported.

In this work, we demonstrate integration of OT with a DMF platform for trapping bacteria of interest captured on MBs (Figure 1). Individual cells of Salmonella enterica serovar Typhimurium (further referred to as Salmonella) were first captured in the microwell array of the DMF platform (Figure 2a) using MBs functionalized with anti-Salmonella antibody (Figure 2b, left), forming Salmonella-bead complexes (Figure 2b, right). Subsequently, OT were used for selective trapping of a complex in a primary microwell $\left(\mu \mathrm{w}_{\mathrm{p}}\right)$ array (Figure $2 \mathrm{c}$, left) and relocation to a secondary microwell $\left(\mu \mathrm{w}_{\mathrm{s}}\right)$ array (Figure 2c, right). To perform this, cells of interest were selected based on the expression of fluorescent proteins. Finally, the cells were incubated with a lysogeny broth (LB)-Agar patch on top and analyzed for proliferation (Figure 2d). This work thus offers the possibility to spatially organize single bacteria in a $2 \mathrm{D}$ format and allows for selecting bacteria at a single-cell resolution, which is challenging with conventional techniques. 


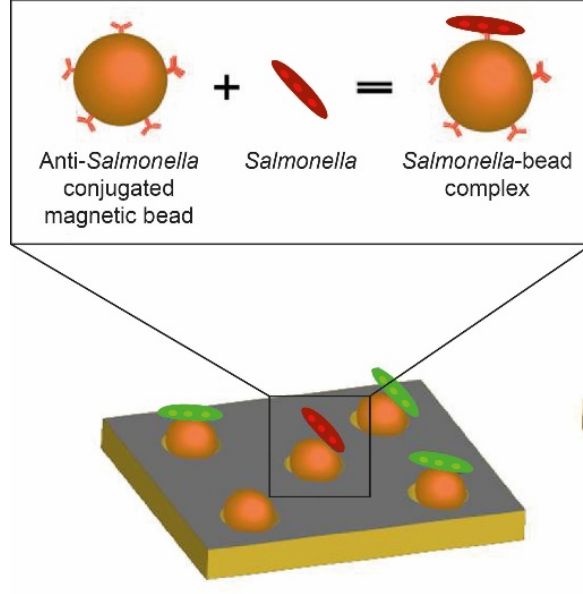

Bacteria screening using fluorescence microscopy

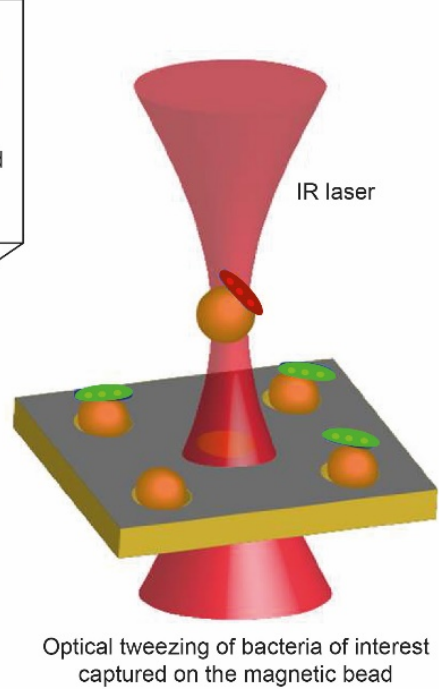

Figure 1. Salmonella bacteria bind to MBs conjugated with anti-Salmonella antibody, forming thereby Salmonella-bead complex, which is subsequently captured using infrared (IR) laser-based OT.

(a) Assembly of DMF platform

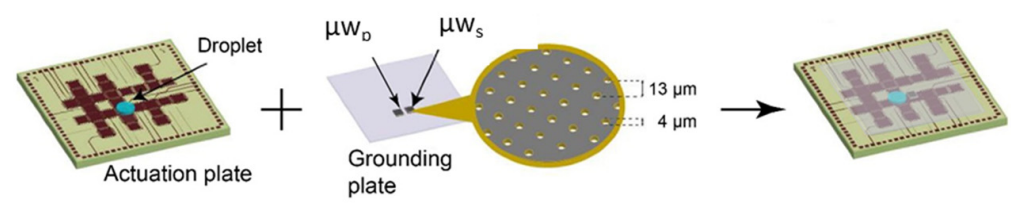

(b) Seeding of MBs on DMF platform + capture of single bacteria on MBs

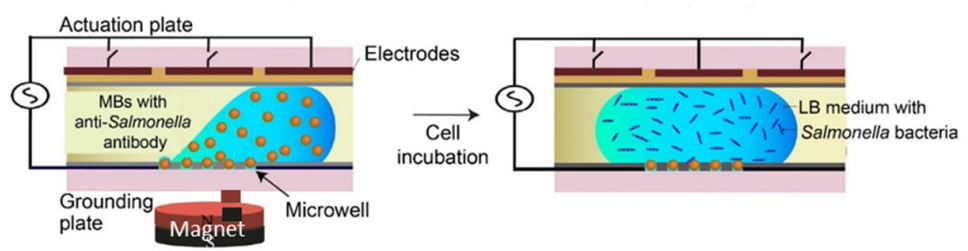

(c) Trapping and relocation of MB with single bacteria from $\mu \mathrm{w}_{\mathrm{p}}$ to $\mu \mathrm{w}_{\mathrm{s}}$ using OT

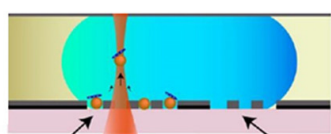

$\mu \mathrm{w}_{\mathrm{p}}$

\section{$\overrightarrow{\text { Bacteria }}$ relocation}

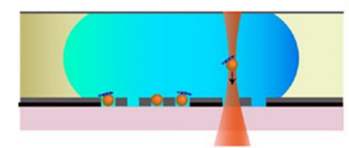

(d) Transfer of selected bacterium to LB-Agar patch for growth and off-chip analysis

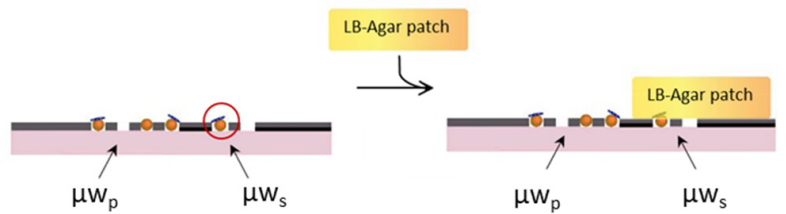

Figure 2. Schematic representation of using the OT-integrated DMF platform for capturing single bacterial cells from microwells, and their subsequent transfer for off-chip analyses. (a) Assembly of the DMF platform, comprising an actuation and grounding plate. The grounding plate contains the $\mu w_{p}$ array and $\mu w_{s}$ array. (b) Manual seeding of MBs (functionalized with anti-Salmonella antibody) in the $\mu \mathrm{w}_{\mathrm{p}}$ array, and capturing of Salmonella on the MBs. (c) OT-mediated trapping and relocation of bacteria of interest from $\mu \mathrm{w}_{\mathrm{p}}$ to $\mu \mathrm{w}_{\mathrm{s}}$, performed after disassembly of the DMF platform by removing the actuation plate. (d) LB-agar patch was manually placed on the $\mu \mathrm{w}_{\mathrm{s}}$ to allow growth of a colony from the relocated bacterium of interest (red circle). 


\section{Materials and Methods}

\subsection{Materials}

LB, phosphate buffered saline (PBS), sodium chloride, Tween 40, Tween 60, and Tween 80 were purchased from Sigma Aldrich (Oakville, ON, USA). Fluorinert FC-40 was purchased from 3M (St. Paul, MN, USA) and chemicals for photolithography were supplied by Rohm and Haas (Marlborough, MN, USA). Fluoroalkylsilane Dynasylan F 8263 was supplied by Evonik (Essen, Germany). AZ1505 photoresist and Teflon-AFR were procured from Microchemicals GmbH (Ulm, Germany) and DuPont (Wilmington, DE, USA), respectively. Parylene-C dimer and Silane A174 were purchased from Plasma Parylene Coating Services (Rosenheim, Germany) and superparamagnetic Dynabeads M-280 Tosylactivated were purchased from Thermo Fisher Scientific (Waltham, MA, USA). Ampicillin and isopropyl $\beta$-D-1-thiogalactopyranoside (IPTG) were procured from Applichem, Darmstadt, Germany, and L-Arabinose from Acros Organics. Mouse monoclonal anti-Salmonella typhimurium LPS antibody (ab8274) was obtained from Abcam (Cambridge, UK).

\subsection{Digital Microfluidic Platform}

The DMF platform consists of: (1) a grounding plate with $\mu \mathrm{w}_{\mathrm{p}}$ array and $\mu \mathrm{w}_{\mathrm{s}}$ array (at least $1 \mathrm{~cm}$ apart) each with 62,500 microwells; and (2) an actuation plate, specifically designed to accommodate and optically visualize both microwell arrays (Figure 2a). Fabrication of the DMF plates was previously described by Witters and co-workers [40,41], and the DMF-operation by Decrop and co-workers [40]. Any adaptations to these are delineated in Section S1. The seeding of MBs, droplet addition, and LB-agar patch attachment and detachment was done manually, while all other manipulations were DMF-mediated.

\subsection{Cell Culture}

Salmonella enterica serovar Typhimurium (strain LT2) containing the motility limiting mudY insertion (Salmonella Typhimurium LT2 fliC::MudY) [42,43] was used for microscopy monitoring and manipulation. For conditional expression of mCherry or green fluorescent protein (GFP), the cells were transformed with either pTrc99A-P trc - mCherry or pFPV-P $_{B A D}-\mathrm{GFP}$ (pAA100 [44]) vector, respectively. The pTrc99A- $\mathrm{P}_{t r c}-\mathrm{mCherry}$ vector was constructed by ligating an mCherry amplicon into a pTrc99A backbone using EcoRI and BamHI restriction sites. The constructed vector was subsequently verified by both PCR and sequencing (Macrogen, the Netherlands). For culturing of bacteria, LB medium was used either as liquid or solid medium after the addition of $1.52 \%$ agar [45]. Stationary phase cultures were obtained by growing Salmonella cells overnight for approximately $20 \mathrm{~h}$ in LB broth at $37^{\circ} \mathrm{C}$ under well aerated conditions (200 rpm on an orbital shaker). Ampicillin (100 $\mu \mathrm{g} / \mathrm{mL})$ and either IPTG (1 mM) or L-arabinose $(0.02 \%)$ were added to the medium at the indicated final concentrations, for induction of mCherry and GFP expression, respectively.

\subsection{MB Functionalization}

Tosyl-activated MBs $(2.5 \mathrm{mg}, 83 \mu \mathrm{L})$ were washed three times in $500 \mu \mathrm{L} 0.1 \mathrm{M}$ Na-phosphate buffer ( $\mathrm{pH}$ 7.4). The MBs were then suspended in $75 \mu \mathrm{L}$ of $0.1 \mathrm{M}$ Na-phosphate buffer (pH 7.4) and $50 \mu \mathrm{L}$ of $3 \mathrm{M}$ ammonium sulfate buffer ( $\mathrm{pH}$ 7.4). The suspension was combined with anti-Salmonella antibody (final concentration: $0,0.03,0.06,0.12$, or $0.24 \mu \mathrm{g} / \mu \mathrm{L}$ ) and incubated with rotation at $1400 \mathrm{rpm}$ for $18 \mathrm{~h}$ at $37^{\circ} \mathrm{C}$. After incubation, the MBs were magnetically separated, and the supernatant was discarded. The MBs were resuspended with blocking buffer (0.01 M Na-phosphate buffer with $0.2 \%$ BSA, pH 7.4) and incubated on a rotator at $1400 \mathrm{rpm}$ for $2 \mathrm{~h}$ at $37^{\circ} \mathrm{C}$. Finally, the MBs were washed 2 times in $500 \mu \mathrm{L}$ storage buffer (0.01 M Na-phosphate buffer with 0.1\% BSA, pH 7.4). The functionalized MBs were resuspended in $120 \mu \mathrm{L}$ storage buffer (final bead concentration of $4.6 \times 10^{5}$ beads $/ \mu \mathrm{L}$ ) and stored at $4{ }^{\circ} \mathrm{C}$. 


\subsection{Working Buffer Optimization}

For efficient retrieval of MBs using OT, an optimal working buffer composition was required. To achieve that, a panel of different buffer compositions was tested for conducting the initial screening. All buffers were prepared starting from a $1 \times$ PBS buffer, varying three parameters: salt concentration $(\mathrm{NaCl})$, surfactant type and surfactant concentration. An I-optimal design of experiments (DOE) was constructed using the JMP software (Pro12, SAS Institute Inc., Cary, NC, USA), where salt and surfactant concentrations were set as continuous variables and surfactant type was taken as a discrete variable [46]. According to the design, 18 feasible buffers were prepared, based on the combinations of the three variables. The detailed buffer compositions are presented in Table S1. For on-chip testing, MBs were washed twice with $200 \mu \mathrm{L}$ of respective buffer and resuspended at a final concentration of $2.5 \times 10^{4}$ beads $/ \mu \mathrm{L}$ for testing on the microwell array. A $10 \mu \mathrm{L}$ droplet of MB suspension was placed on the microwell array of the grounding plate and manually moved 13-15 times over the microwell array using a pipette tip. A small magnet (NeFeB, $5 \mathrm{~mm}$ diameter, $3 \mathrm{~mm}$ thickness, $6.86 \mathrm{~N}$, Supermagnete, Gottmadingen, Germany) was placed beneath the microwell array to improve the seeding efficiency. Seeded MBs were then covered with a fresh droplet of the same buffer on the microwell array. The MB vibrations were recorded using a bright field microscope (Eclipse Ti, Nikon, Tokyo, Japan) equipped with a CMOS camera (Zyla 3-tap, Andor, Belfast, UK). The fraction of vibrating MBs from the total seeded MBs was determined and used for analysis.

\subsection{Salmonella Capture on Microarray}

MBs suspended in the optimal working buffer, at a final concentration of $2.5 \times 10^{4}$ beads/ $\mu \mathrm{L}$, were manually seeded in the $\mu \mathrm{w}_{\mathrm{p}}$ array with the aid of a magnet, as indicated before (Figure $2 \mathrm{~b}$, left). The droplet containing MBs was replaced by the droplet containing Salmonella suspension, with roughly $5 \times 10^{4}$ cells $/ \mu \mathrm{L}(2.7 \mu \mathrm{L}, 1 / 20$ diluted in working buffer) (Figure $2 \mathrm{~b}$, right). Next, the grounding and actuation plates were assembled into the DMF chip and $80 \mu \mathrm{L}$ silicon oil was added between the plates to avoid evaporation of the droplets. The $\mu \mathrm{w}_{\mathrm{p}}$ array was incubated with the Salmonella droplet for $30 \mathrm{~min}$ before being actuated away from the microwell array. Subsequently, the $\mu_{\mathrm{p}}$ array was washed twice with the working buffer via DMF-mediated actuation of $2.7 \mu \mathrm{L}$ droplets (placed on grounding plate prior chip assembly) to remove any nonspecific binding of bacteria. Fluorescence and bright field images (for detecting MBs) were collected using $60 \times$ magnification on an inverted fluorescence microscope (Eclipse Ti, Nikon, Tokyo, Japan). Images were processed in ImageJ software $(1.47 \mathrm{v}, \mathrm{NIH}, \mathrm{MD})$ as follows: background subtraction was performed using the rolling ball algorithm with a radius of 50 pixels and salt and pepper noise was removed using the despeckle option. The images were used for counting two events: (i) the number of MBs carrying at least 1 bacteria (at all antibody concentrations); and (ii) the number of bacteria conjugated per MB (only at 0.12 and $0.24 \mu \mathrm{g} / \mu \mathrm{L}$ antibody concentrations). For the former type of analysis, a grayscale dilation of pixels was performed by applying a maximum filter in the images. In this way, a single bright spot was observed on the MB carrying bacteria, irrespective of the number of bacteria-conjugated to MB. For the latter type of analysis, pixel dilation was not performed and number of bacteria per image were counted manually.

\subsection{Selective Retrieval of Single Salmonella Bacterium}

For selective retrieval of bacteria conjugated to MBs, the previously described OT platform was utilized [38]. In this study, two excitation/emission filters were used for fluorescence applications: FITC ex465-495/em515-555 (for detecting GFP) and TRITC ex540-575/em605-655 (for detecting mCherry). Imaging was done with a Zyla 3-tap CMOS camera (Andor, Belfast, UK). The grounding plate (disassembled from the actuation plate with the magnet still placed underneath), containing both microwell arrays, was positioned on a motorized stage (SCAN IM 120x100, Märzhäuser Wetzlar GmbH \& Co.KG, Wetzlar, Germany), facilitating accurate positioning $(0.1 \mu \mathrm{m})$ of the MBs. Bacteria conjugated 
to MBs were screened with fluorescence microscopy based on GFP or mCherry fluorescence. Bacteria of interest were held in the optical trap for translocation within the $\mu \mathrm{w}_{\mathrm{p}}$ or from the $\mu \mathrm{w}_{\mathrm{p}}$ to a $\mu \mathrm{w}_{\mathrm{S}}$ (Figure 2c) by repositioning the $\mathrm{MB}$ via changes in the $\mathrm{x}$ - and $\mathrm{y}$-axis of the microscope stage. To re-seed the trapped bead in the $\mu \mathrm{w}_{\mathrm{s}}$, the $\mathrm{z}$-axis of the optical trap was lowered and the aperture of the IR laser was subsequently closed. Following successful repositioning of bacteria, the grounding plate was disconnected from the OT setup and the working buffer on the $\mu \mathrm{w}_{\mathrm{s}}$ replaced with a $1 \mathrm{~cm} \times 1 \mathrm{~cm}$ LB-agar-ampicillin patch (Figure $2 \mathrm{~d}$ ). The array, with this patch, was incubated at $37^{\circ} \mathrm{C}$ to allow bacterial proliferation which was measured after $10 \mathrm{~h}$ using fluorescence and brightfield imaging.

\section{Results and Discussion}

\subsection{Buffer Selection for OT-Mediated Retrieval of MBs}

As previously described by Decrop et al. [38,39], buffer composition is an important aspect for Brownian motion of MBs seeded in microwells, and thus critical for their optical trapping. Therefore, an optimal buffer in this study was selected by performing DOE for investigating salt concentration $(\mathrm{NaCl})$, surfactant type, and surfactant concentration. An I-optimal experimental design was established using the JMP software that prescribed 18 buffer conditions for experimental testing. After determining the fraction of vibrating MBs, the statistical analysis indicated a significant main effect (salt concentration, $p=0.0004$ ) and a significant interaction effect (surfactant type $\times$ salt concentration, $p=0.009$ ), positively influencing the fraction of vibrating MBs. A goodness of fit comparison between predicted and experimental fractions of vibrating MBs resulted in a $\mathrm{R}^{2}$ value of 0.88 (Figure $\mathrm{S} 1$ ). To determine the optimal buffer composition, a prediction profiler was generated based on the predicted response and the significant effects. A PBS buffer supplemented with $0.1 \%(v / v)$ Tween 40 and $171 \mathrm{mM} \mathrm{NaCl}$ (final $\mathrm{NaCl}$ concentration in PBS: $308 \mathrm{mM}$ ) was found as the most optimal, with a maximum predicted fraction of $27.6 \%$ vibrating MBs (Figure 3). This fraction was not further maximized keeping in view the cytotoxic effect of salt $[47,48]$ and surfactants $[49,50]$.

(a)

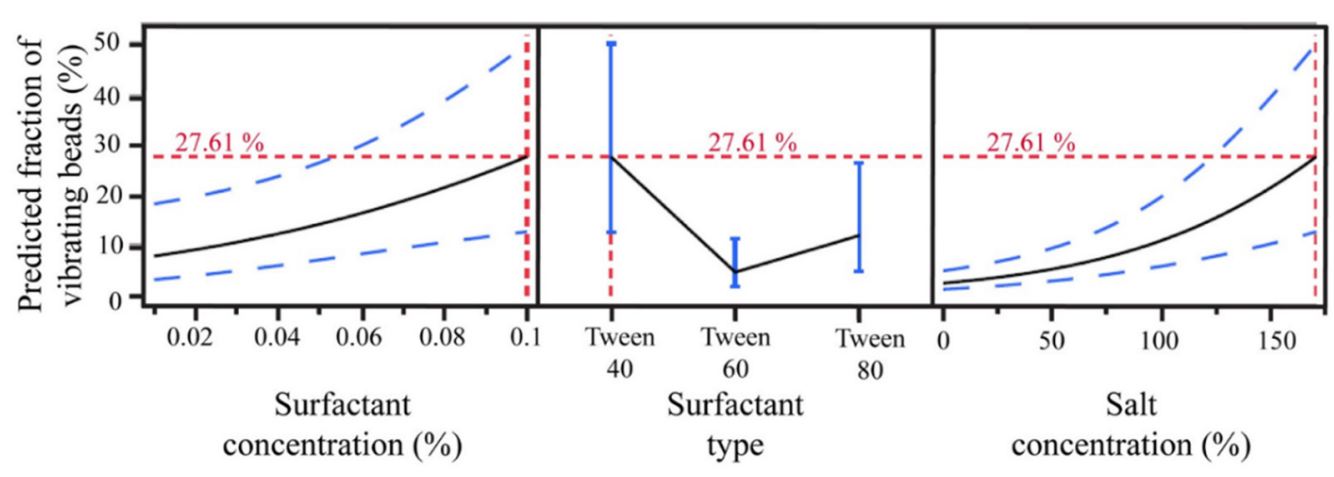

Figure 3. Prediction profiler for evaluating the optimal working buffer composition modeled on: (a) surfactant concentration; (b) surfactant type; and (c) salt concentration. The dotted blue and red lines indicate the confidence interval and maximum predicted fraction of vibrating MBs, respectively.

Using the optimal buffer composition, MBs manually seeded in the microwells were retrieved with the OT, achieving a successful retrieval efficiency of $21.3 \pm 4.2 \%(n=3)$. This efficiency was slightly lower than the predicted maximum fraction of vibrating beads $(27.6 \%)$, yet still within the predicted variation interval of $(12.6 \%, 50.1 \%)$ (Figure 3). The MBs were observed to be sticking to the microwell as well as escaping the OT trap, possibly due to imbalance of electrostatic charges, resulting in a retrieval efficiency lower than predicted. This may be alleviated by incorporating different chemistries to lower cell sticking to the surface [51]. 


\subsection{Capturing Single Salmonella Cells on MBs}

The MBs functionalized with anti-Salmonella antibody were manually seeded in microwells, followed by capturing the non-motile strain of Salmonella equipped with the mCherry plasmid on the MBs by incubating a droplet containing bacteria over the microwell array. Next, DMF-mediated removal of bacterial droplet and washing of MBs was undertaken. mCherry fluorescence, measured using fluorescence microscopy, was used to calculate the fraction of MBs with captured bacteria. As depicted in Figure $4 \mathrm{a}$, the fraction of MBs with at least one captured bacterium gradually increased from $14 \%$ to $47 \%$ with increasing antibody concentration used for functionalization of MBs (from 0.0 to $0.24 \mu \mathrm{g} / \mu \mathrm{L}$ ) (Figure S2). Following this preliminary analysis, we further evaluated the number of bacteria captured per $\mathrm{MB}$ at the two highest antibody concentrations. For the $0.12 \mu \mathrm{g} / \mu \mathrm{L}$ antibody concentration, the average fraction of MBs carrying one or two bacteria was $32.8 \%$ and $2.3 \%$, respectively, which increased to $44.5 \%$ and $2.7 \%$ for the $0.24 \mu \mathrm{g} / \mu \mathrm{L}$ antibody concentration (Figure $4 \mathrm{~b}$ ). Occurrences of single $\mathrm{MB}$ carrying two bacteria were observed in both the concentrations. However, such occurrences were significantly lower than the fraction of MB carrying single bacteria $(p<0.05)$. In addition, the difference in the fraction of MBs carrying two bacteria at 0.12 and $0.24 \mu \mathrm{g} / \mu \mathrm{L}$ antibody concentrations was not statistically significant. Importantly, no MB was observed carrying more than two bacteria for any of the antibody concentrations used. Because the $0.24 \mu \mathrm{g} / \mu \mathrm{L}$ antibody concentration maximized bacterial capture efficiency, it was implemented for all subsequent OT retrieval and capture experiments. In addition, because no unbound bacteria were observed on the arrays during this work, we concluded that the two washing steps were sufficient for removal of all unbound bacteria.

(a)

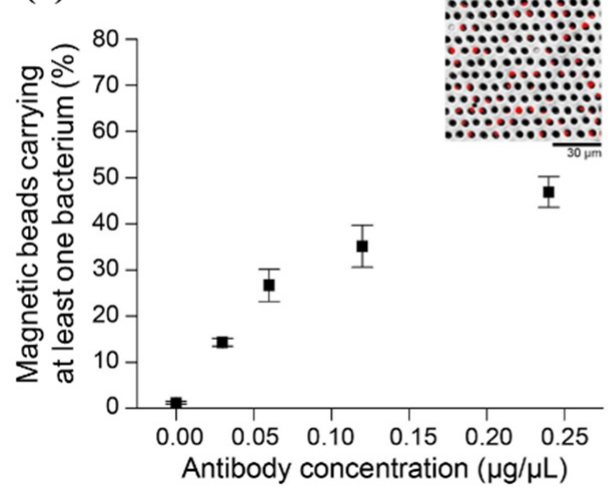

(b)

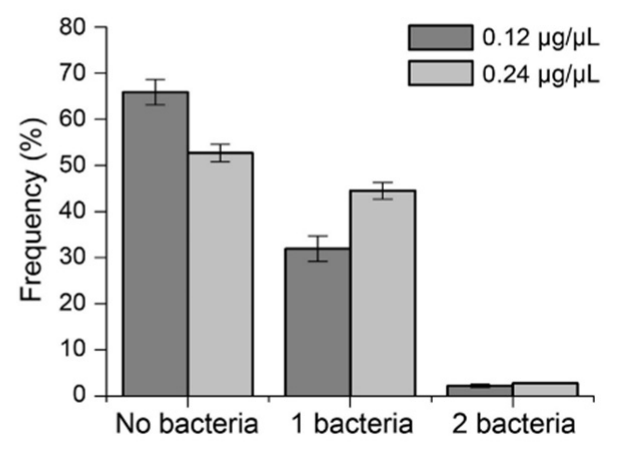

Figure 4. Optimization of immobilized antibody concentration for efficient capture of bacteria on MBs. (a) Increase in fraction of MBs carrying at least one bacterium with an increase in antibody concentration can be seen, as analyzed based on fluorescence from mCherry bacteria (inset). For each point, a minimum of 11,500 beads were analyzed over three independent repetitions. (b) At 0.12 and $0.24 \mu \mathrm{g} / \mu \mathrm{L}$ of anti-Salmonella antibody concentrations, the number of bacteria captured per MB was determined. Error bars represent standard error of the mean of triplicate measurements.

Following Salmonella capture on MBs, the OT were utilized for retrieval of MBs bound with a single bacterium (MB-SB), where the MB acted as the handle for the OT. Figure 5a displays the OT-mediated relocation of a selected MB-SB (with an mCherry) from the yellow dotted circle (Figure 5a-i) to the green dashed circle (Figure 5a-iii) within the same $\mu \mathrm{w}_{\mathrm{p}}$ array (images are screenshots of Video S1). The trapping technique was also successfully utilized to spatially arrange individual GFP- or mCherry-expressing bacteria captured on MBs on the microarray, as shown in Figure 5b. Collectively, demonstrated precise control for single-cell manipulation offered by the OT-integrated DMF platform holds great promise for further single-cell sorting and analysis studies. 
(a)

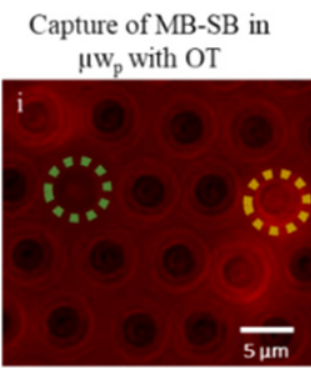

(b)

\section{Control MB}

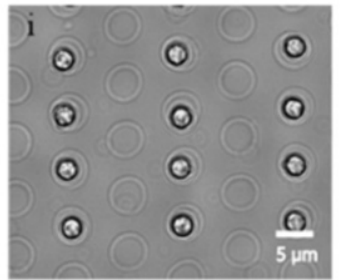

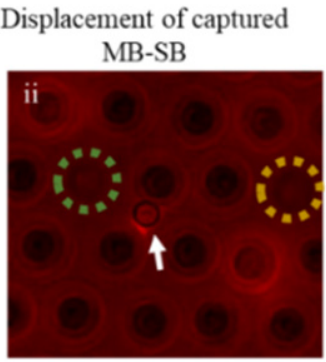

MB with GFP-expressing Salmonella

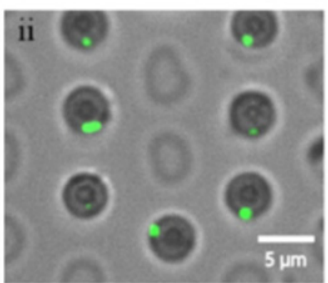

Relocation of MB-SB in

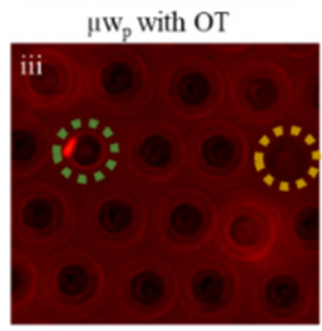

MB with mCherry-expressing Salmonella

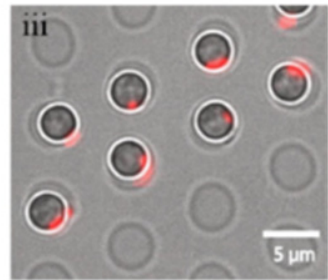

Figure 5. OT-mediated selective retrieval of single bacteria. (a-i) MB-SB with mCherry-expression was retrieved from one microwell (yellow circle), (a-ii) held in OT-trap, and (a-iii) relocated to another microwell (green circle) on the same $\mu \mathrm{w}_{\mathrm{p}}$ array, in $\sim 20 \mathrm{~s}$. The OT-held MB-SB during relocation is marked with an arrow in (a-ii). (b-i) Control MBs, (b-ii) MBs with GFP-expressing Salmonella, and (b-iii) MBs with mCherry-expressing Salmonella selectively repositioned using OT.

\subsection{Growth in Agar Patch}

The selective retrieval, transfer, and growth of bacteria of interest for off-chip analysis was also realized using the OT setup. An MB of interest, carrying bacteria with mCherry expression (Figure 6a), was successfully transferred from a $\mu w_{P}$ to a $\mu w_{S}$ array using OT. The working buffer was replaced with an LB-agar patch (supplemented with arabinose for induction of mCherry expression) (Figure 2d). After allowing bacterial growth at $37^{\circ} \mathrm{C}$ for $10 \mathrm{~h}$ under the agar patch, imaging revealed that the array retained a fully grown colony, originating from the selected relocated bacteria and infiltrating the entire array (Figure 6a-ii,iii). Here, to avoid optical noise from the overlying bacteria, fluorescence images were focused at the bottom part of the microwell array. In the $\mu \mathrm{w}_{\mathrm{s}}$ array, enclosed air bubbles were occasionally observed. Such air bubbles were not observed in the $\mu \mathrm{w}_{\mathrm{p}}$ array where MB-SB seeding was performed in the presence of a magnet, as strong magnetic forces pull the MB-SB inside the microwell, thereby displacing the air. The same experiment was performed with MB carrying GFP-expressing bacteria (Figure 6b) using an agar patch supplemented with IPTG, instead of arabinose, for induction of GFP expression. 
(a)

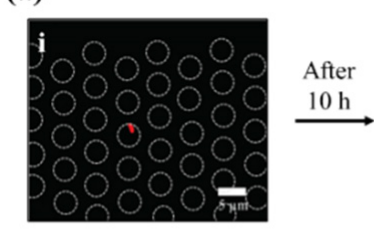

(b)

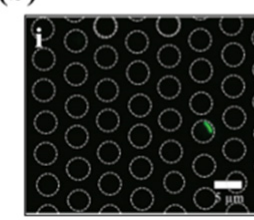

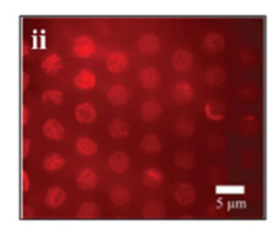
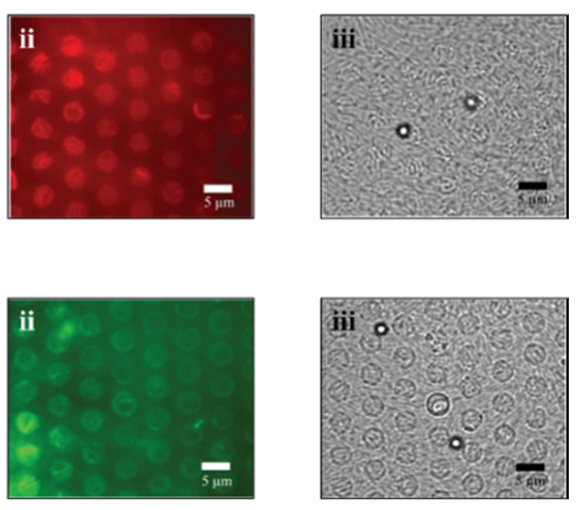

Figure 6. OT-mediated relocation of MB-SB from a $\mu \mathrm{w}_{\mathrm{P}}$ to a $\mu \mathrm{w}_{\mathrm{S}}$ array for bacteria growth under LB-agar patch. (a-i) Fluorescence image of $\mu \mathrm{w}_{\mathrm{s}}$ array with mCherry-expressing bacteria on MB at $0 \mathrm{~h},(\mathbf{a}-\mathbf{i i})$ and at $10 \mathrm{~h}$. (a-iii) Brightfield image of $\mu \mathrm{w}_{\mathrm{s}}$ array with mCherry-expressing bacteria on MB. (b-i) Fluorescence image of $\mu \mathrm{w}_{\mathrm{s}}$ array with GFP-expressing bacteria on MB at $0 \mathrm{~h}$, (b-ii) and at $10 \mathrm{~h}$. (b-iii) Brightfield image of $\mu \mathrm{w}_{\mathrm{s}}$ array with GFP-expressing bacteria on MB. Single MB carrying mCherry-expressing (a) and GFP-expressing (b) bacteria were relocated to a $\mu \mathrm{w}_{\mathrm{s}}$ array (a-i and $\mathbf{b}-\mathbf{i}$, respectively), and incubated under a LB-agar patch for proliferation. Fluorescence (ii) and brightfield (iii) images taken after $10 \mathrm{~h}$ demonstrated successful, confluent bacterial growth in both the relocated mCherry- and GFP-expressing bacteria. The white dots seen in (a-iii) and (b-iii) are the MBs, from relocated $\mathrm{MB}-\mathrm{SB}$, under brightfield.

\section{Conclusions}

The current study demonstrated the ability of the OT-integrated DMF platform for capturing and retrieving bacteria at a single-cell level. To achieve this, the DMF platform consisting of two plates was employed, where microwell arrays were incorporated in the grounding plate. Fluorescence microscopy was utilized to monitor the mCherry and GFP expression continuously during operation: (i) to verify bacterial binding on MBs; (ii) to select MB-SB of interest; and (iii) to validate the proliferation of bacteria. As Brownian motion of MBs is crucial for successful OT [38], we firstly applied DOE for selection of the optimal buffer that allowed effective Brownian motion of MBs used in this study. Next, bacterial capture efficiency of antibody-conjugated MBs was evaluated, and an antibody concentration of $0.24 \mu \mathrm{g} / \mathrm{mL}$ was chosen for MB-functionalization to maximize capture efficiency. Using OT, the MB-SB were captured in microwells and successfully relocated, both on the same array and on different arrays. The former demonstrated controlled, spatial organization of optically retrieved single-cells on the DMF platform, whereas the latter demonstrated successful bacterial proliferation after OT-mediated manipulations, thus indicating bacterial viability.

In this study, IR OT were used $(\lambda=1064 \mathrm{~nm}$ wavelength, $500 \mathrm{~mW})$ to indirectly manipulate bacteria conjugated to $\mathrm{MB}$, where $\mathrm{MB}$ acts as handle [52]. In such cases, the handle can possibly absorb photons from the laser, thereby heating up and transferring the generated heat to the bacteria [53], which can impact cellular responses and thus interfere with analyses. Although our results already suggest that manipulated bacteria can grow and proliferate on the LB-agar patch, future work might focus on testing oscillating OT [54] or combination of different wavelengths/lower power to obviate any ill effects OT treatment that may incur on cellular responses. Alternatively, to reduce photo-damage, an enzymatic scavenging system may be introduced in the medium for removing molecular oxygen [55].

In conclusion, this study successfully demonstrated the selective retrieval of single bacteria from a population and presented OT-integrated DMF platform as a tool for manipulating and retrieving single-cells for proliferation, and potential off-chip analysis. This work has brought forth the utility of this coupled technology as a whole, and specifically for its application in library screening and single-cell studies. 
Supplementary Materials: The following are available online at http://www.mdpi.com/2072-666X/11/3/308/s1, Section S1: Fabrication of DMF platform, Table S1: Buffer composition, Figure S1: Goodness of fit plot, Figure S2: Capture of Salmonella on MBs, Video S1: Optical tweezing of bacteria.

Author Contributions: Conceptualization, P.T.K., D.D., I.P., A.A. and J.L.; Data curation, P.T.K. and D.D.; Formal analysis, P.T.K. and D.D.; Funding acquisition, J.L., D.S., and A.A.; Investigation, P.T.K. and D.D.; Methodology, P.T.K., D.D., A.A., and J.L.; Resources, I.P., R.P., A.A., and J.L.; Supervision, T.K., D.S., and J.L.; Validation, P.T.K., D.D., S.S., D.S., and J.L.; Visualization, P.T.K., D.D., and S.S.; Writing-original draft, P.T.K., D.D., and S.S.; and Writing-review and editing, D.D., S.S., A.A., D.S., and J.L. All authors have read and agreed to the published version of the manuscript.

Funding: This work received funding from KU Leuven Research Fund (DBOF-grant P.T.K., IDO/10/012, PDM 17-093 D.D.), the European Union's Horizon 2020 research and innovation programme under the Marie Skłodowska-Curie grant agreement No. 675412 (H2020-MSCA-ITN-ND4ID), doctoral fellowships from the Flemish Agency for Innovation by Science and Technology (IWT-Vlaanderen D.D. and I.P.), and Research Foundation-Flanders (FWO G080016N).

Acknowledgments: The authors would like to thank Sander K. Govers for construction of the pTrc99A-Ptrc-mCherry vector.

Conflicts of Interest: The authors declare no conflict of interest. The funders had no role in the design of the study; in the collection, analyses, or interpretation of data; in the writing of the manuscript, or in the decision to publish the results.

\section{References}

1. Elowitz, M.B.; Levine, A.J.; Siggia, E.D.; Swain, P.S. Stochastic gene expression in a single cell. Science 2002, 297, 1183-1186. [CrossRef]

2. Glauche, I.; Thielecke, L.; Roeder, I. Cellular aging leads to functional heterogeneity of hematopoietic stem cells: A modeling perspective. Aging Cell 2011, 10, 457-465. [CrossRef]

3. Huh, D.; Paulsson, J. Random partitioning of molecules at cell division. Proc. Natl. Acad. Sci. USA 2011, 108, 15004-15009. [CrossRef]

4. Levchenko, A.; Nemenman, I. Cellular noise and information transmission. Curr. Opin. Biotechnol. 2014, 28, 156-164. [CrossRef]

5. Govers, S.K.; Mortier, J.; Adam, A.; Aertsen, A. Protein aggregates encode epigenetic memory of stressful encounters in individual Escherichia coli cells. PLoS Biol. 2018, 16, e2003853. [CrossRef]

6. Wu, H.; Zhang, X.-Y.; Hu, Z.; Hou, Q.; Zhang, H.; Li, Y.; Li, S.; Yue, J.; Jiang, Z.; Weissman, S.M.; et al. Evolution and heterogeneity of non-hereditary colorectal cancer revealed by single-cell exome sequencing. Oncogene 2017, 36, 2857-2867. [CrossRef] [PubMed]

7. Kuipers, J.; Jahn, K.; Beerenwinkel, N. Advances in understanding tumour evolution through single-cell sequencing. Biochim. Biophys. Acta - Rev. Cancer 2017, 1867, 127-138. [CrossRef] [PubMed]

8. Helaine, S.; Holden, D.W.; Mouton, J.M.; Sampson, S.L. Elucidating population-wide mycobacterial replication dynamics at the single-cell level. Microbiology 2016, 162, 966-978.

9. Davis, K.M.; Isberg, R.R. Defining heterogeneity within bacterial populations via single cell approaches. BioEssays 2016, 38, 782-790. [CrossRef]

10. Passaris, I.; Cambré, A.; Govers, S.K.; Aertsen, A. Bimodal expression of the salmonella typhimurium spv operon. Genetics 2018. [CrossRef]

11. Clark, S.J.; Lee, H.J.; Smallwood, S.A.; Kelsey, G.; Reik, W. Single-cell epigenomics: powerful new methods for understanding gene regulation and cell identity. Genome Biol. 2016, 17, 72. [CrossRef] [PubMed]

12. Cheow, L.F.; Courtois, E.T.; Tan, Y.; Viswanathan, R.; Xing, Q.; Tan, R.Z.; Tan, D.S.W.; Robson, P.; Loh, Y.-H.; Quake, S.R.; et al. Single-cell multimodal profiling reveals cellular epigenetic heterogeneity. Nat. Methods 2016, 13, 833-836. [CrossRef] [PubMed]

13. Patel, A.P.; Tirosh, I.; Trombetta, J.J.; Shalek, A.K.; Gillespie, S.M.; Wakimoto, H.; Cahill, D.P.; Nahed, B.V.; Curry, W.T.; Martuza, R.L.; et al. Single-cell RNA-seq highlights intratumoral heterogeneity in primary glioblastoma. Science 2014, 344, 1396-1401. [CrossRef] [PubMed]

14. Chen, C.-L.; Mahalingam, D.; Osmulski, P.; Jadhav, R.R.; Wang, C.-M.; Leach, R.J.; Chang, T.-C.; Weitman, S.D.; Kumar, A.P.; Sun, L.; et al. Single-cell analysis of circulating tumor cells identifies cumulative expression patterns of EMT-related genes in metastatic prostate cancer. Prostate 2013, 73, 813-826. [CrossRef]

15. Eisenstein, M. Cell sorting: Divide and conquer. Nature 2006, 441, 1179-1185. [CrossRef] 
16. Yanez, L.Z.; Camarillo, D.B. Microfluidic analysis of oocyte and embryo biomechanical properties to improve outcomes in assisted reproductive technologies. MHR Basic Sci. Reprod. Med. 2017, 23, 235-247. [CrossRef]

17. Mellors, J.S.; Jorabchi, K.; Smith, L.M.; Ramsey, J.M. Integrated Microfluidic Device for Automated Single Cell Analysis Using Electrophoretic Separation and Electrospray Ionization Mass Spectrometry. Anal. Chem. 2010, 82, 967-973. [CrossRef]

18. Attayek, P.J.; Waugh, J.P.; Hunsucker, S.A.; Grayeski, P.J.; Sims, C.E.; Armistead, P.M.; Allbritton, N.L. Automated microraft platform to identify and collect non-adherent cells successfully gene-edited with CRISPR-Cas9. Biosens. Bioelectron. 2017, 91, 175-182. [CrossRef]

19. Kokkinis, G.; Cardoso, S.; Keplinger, F.; Giouroudi, I. Microfluidic platform with integrated GMR sensors for quantification of cancer cells. Sensors Actuators B Chem. 2017, 241, 438-445. [CrossRef]

20. Benítez, J.J.; Topolancik, J.; Tian, H.C.; Wallin, C.B.; Latulippe, D.R.; Szeto, K.; Murphy, P.J.; Cipriany, B.R.; Levy, S.L.; Soloway, P.D.; et al. Microfluidic extraction, stretching and analysis of human chromosomal DNA from single cells. Lab Chip 2012, 12, 4848. [CrossRef]

21. Iino, R.; Hayama, K.; Amezawa, H.; Sakakihara, S.; Kim, S.H.; Matsumono, Y.; Nishino, K.; Yamaguchi, A.; Noji, H. A single-cell drug efflux assay in bacteria by using a directly accessible femtoliter droplet array. Lab Chip 2012, 12, 3923. [CrossRef] [PubMed]

22. Snider, A.; Pirozzi, I.; Tripathi, A. Centrifugal Microfluidics Traps for Parallel Isolation and Imaging of Single Cells. Micromachines 2020, 11, 149. [CrossRef] [PubMed]

23. Zhu, C.; Luo, X.; Espulgar, W.V.; Koyama, S.; Kumanogoh, A.; Saito, M.; Takamatsu, H.; Tamiya, E. Real-Time Monitoring and Detection of Single-Cell Level Cytokine Secretion Using LSPR Technology. Micromachines 2020, 11, 107. [CrossRef] [PubMed]

24. Steubing, R.W.; Cheng, S.; Wright, W.H.; Numajiri, Y.; Berns, M.W. Laser induced cell fusion in combination with optical tweezers: The laser cell fusion trap. Cytometry 1991, 12, 505-510. [CrossRef] [PubMed]

25. Zhu, R.; Avsievich, T.; Bykov, A.; Popov, A.; Meglinski, I. Influence of Pulsed He-Ne Laser Irradiation on the Red Blood Cell Interaction Studied by Optical Tweezers. Micromachines 2019, 10, 853. [CrossRef] [PubMed]

26. Liang, Y.; Liang, G.; Xiang, Y.; Lamstein, J.; Gautam, R.; Bezryadina, A.; Chen, Z. Manipulation and Assessment of Human Red Blood Cells with Tunable "tug-of-War" Optical Tweezers. Phys. Rev. Appl. 2019, 12, 064060. [CrossRef]

27. Berns, M.W.; Wright, W.H.; Tromberg, B.J.; Profeta, G.A.; Andrews, J.J.; Walter, R.J. Use of a laser-induced optical force trap to study chromosome movement on the mitotic spindle. Proc. Natl. Acad. Sci. USA 1989, 86, 4539-4543. [CrossRef]

28. Hou, J.; Luo, T.; Ng, K.L.; Leung, A.Y.H.; Liang, R.; Sun, D. Characterization of Drug Effect on Leukemia Cells Through Single Cell Assay With Optical Tweezers and Dielectrophoresis. IEEE Trans. Nanobiosci. 2016, 15, 820-827. [CrossRef]

29. Ericsson, M.; Hanstorp, D.; Hagberg, P.; Enger, J.; Nyström, T. Sorting out bacterial viability with optical tweezers. J. Bacteriol. 2000, 182, 5551-5555. [CrossRef]

30. Zhao, H.; Chin, L.K.; Shi, Y.; Nguyen, K.T.; Liu, P.Y.; Zhang, Y.; Zhang, M.; Zhang, J.; Cai, H.; Yap, E.P.H.; et al. Massive nanophotonic trapping and alignment of rod-shaped bacteria for parallel single-cell studies. Sens. Actuators B Chem. 2020, 306. [CrossRef]

31. Probst, C.; Grünberger, A.; Wiechert, W.; Kohlheyer, D. Microfluidic growth chambers with optical tweezers for full spatial single-cell control and analysis of evolving microbes. J. Microbiol. Methods 2013, 95, 470-476. [CrossRef] [PubMed]

32. Wessel, A.K.; Hmelo, L.; Parsek, M.R.; Whiteley, M. Going local: technologies for exploring bacterial microenvironments. Nat. Rev. Microbiol. 2013, 11, 337-348. [CrossRef] [PubMed]

33. Quake, S.R.; Fu, A.Y.; Spence, C.; Scherer, A.; Arnold, F.H. A microfabricated fluorescence-activated cell sorter. Nat. Biotechnol. 1999, 17, 1109-1111.

34. Jahan-Tigh, R.R.; Ryan, C.; Obermoser, G.; Schwarzenberger, K. Flow Cytometry. J. Invest. Dermatol. 2012, 132, 1-6. [CrossRef] [PubMed]

35. Keloth, A.; Anderson, O.; Risbridger, D.; Paterson, L. Single cell isolation using optical tweezers. Micromachines 2018, 9, 434.

36. Ng, A.H.C.; Dean Chamberlain, M.; Situ, H.; Lee, V.; Wheeler, A.R. Digital microfluidic immunocytochemistry in single cells. Nat. Commun. 2015, 6, 7513. [CrossRef] [PubMed] 
37. Kumar, P.T.; Vriens, K.; Cornaglia, M.; Gijs, M.; Kokalj, T.; Thevissen, K.; Geeraerd, A.; Cammue, B.P.A.; Puers, R.; Lammertyn, J. Digital microfluidics for time-resolved cytotoxicity studies on single non-adherent yeast cells. Lab Chip 2015, 15, 1852-1860. [CrossRef]

38. Decrop, D.; Brans, T.; Gijsenbergh, P.; Lu, J.; Spasic, D.; Kokalj, T.; Beunis, F.; Goos, P.; Puers, R.; Lammertyn, J. Optical Manipulation of Single Magnetic Beads in a Microwell Array on a Digital Microfluidic Chip. Anal. Chem. 2016, 88, 8596-8603. [CrossRef]

39. Decrop, D.; Brans, T.; Kokalj, T.; Beunis, F.; Lammertyn, J. Magnetic particle retrieval and positioning in a microwell array by integrating optical tweezers in a digital microfluidic platform. In Proceedings of the 18th International Conference on Miniaturized Systems for Chemistry and Life Sciences, MicroTAS 2014, San Antonio, TX, USA, 26-30 October 2014; pp. 1455-1457.

40. Decrop, D.; Ruiz, E.P.; Kumar, P.T.; Tripodi, L.; Kokalj, T.; Lammertyn, J. Digital microfluidics assisted sealing of individual magnetic particles in femtoliter-sized reaction wells for single-molecule detection. In Methods in Molecular Biology; Humana Press: New York, NY, USA, 2017; Volume 1547, pp. 85-101.

41. Witters, D.; Knez, K.; Ceyssens, F.; Puers, R.; Lammertyn, J. Digital microfluidics-enabled single-molecule detection by printing and sealing single magnetic beads in femtoliter droplets. Lab Chip 2013, 13, 2047. [CrossRef]

42. Passaris, I.; Ghosh, A.; Cenens, W.; Michiels, C.W.; Lammertyn, J.; Aertsen, A. Isolation and Validation of an Endogenous Fluorescent Nucleoid Reporter in Salmonella Typhimurium. PLoS ONE 2014, 9, e93785. [CrossRef]

43. Yonekura, K.; Maki-Yonekura, S.; Namba, K. Complete atomic model of the bacterial flagellar filament by electron cryomicroscopy. Nature 2003, 424, 643-650. [CrossRef] [PubMed]

44. Aertsen, A.; Tesfazgi Mebrhatu, M.; Michiels, C.W. Activation of the Salmonella Typhimurium Mrr protein. Biochem. Biophys. Res. Commun. 2008, 367, 435-439. [CrossRef] [PubMed]

45. Bertani, G. Lysogeny at mid-twentieth century: P1, P2, and other experimental systems. J. Bacteriol. 2004, 186, 595-600. [CrossRef] [PubMed]

46. Park, G.J. Analytic Methods for Design Practice; Springer: London, UK, 2007; ISBN 9781846284724.

47. Hajmeer, M.; Ceylan, E.; Marsden, J.L.; Fung, D.Y.C. Impact of sodium chloride on Escherichia coli O157:H7 and Staphylococcus aureus analysed using transmission electron microscopy. Food Microbiol. 2006, 23, 446-452. [CrossRef] [PubMed]

48. Thayer, D.W.; Muller, W.S.; Buchanan, R.L.; Phillips, J.G. Effect of NaCl, pH, temperature, and atmosphere on growth of Salmonella typhimurium in glucose-mineral salts medium. Appl. Environ. Microbiol. 1987, 53, 1311-1315. [CrossRef] [PubMed]

49. Hamzeloo-Moghadam, M.; Taiebi, N.; Mosaddegh, M.; Tehrani, B.E.; Esmaeili, S. The effect of some cosolvents and surfactants on viability of cancerous cell lines. Res. J. pharmacogn. 2014, 1, 41-45.

50. D'Aoust, J.-Y.; Maishment, C.; Stotland, P.; Boville, A. Surfactants for the Effective Recovery of Salmonella in Fatty Foods. J. Food Prot. 1982, 45, 249-252. [CrossRef]

51. Breukers, J.; Struyfs, C.; Decrop, D.; Kil, D.; Thevissen, K.; Cammue, B.; Puers, R.; Lammertyn, J. Tuning the surface interactions between single cells and an OSTE+ microwell array for enhanced optical tweezers manipulation. In Proceedings of the Miniaturized Systems for Chemistry and Life Sciences (MicroTAS) Conference, Kaohsiung, Taiwan, 11-15 November 2018.

52. Molloy, J.E.; Padgett, M.J. Lights, action: Optical tweezers. Contemp. Phys. 2002, 43, 241-258. [CrossRef]

53. Zhang, H.; Liu, K.-K. Optical tweezers for single cells. J. R. Soc. Interface 2008, 5, 671-690. [CrossRef]

54. Zhang, Z.; Kimkes, T.E.P.; Heinemann, M. Manipulating rod-shaped bacteria with optical tweezers. Sci. Rep. 2019, 9, 19086. [CrossRef]

55. Neuman, K.C.; Nagy, A. Single-molecule force spectroscopy: Optical tweezers, magnetic tweezers and atomic force microscopy. Nat. Methods 2008, 5, 491-505. [CrossRef] [PubMed]

(C) 2020 by the authors. Licensee MDPI, Basel, Switzerland. This article is an open access article distributed under the terms and conditions of the Creative Commons Attribution (CC BY) license (http://creativecommons.org/licenses/by/4.0/). 